\title{
Variations of Sediment Archaea Communities in Different Distribution Areas of Bruguiera gymnoihiza Mangrove in Dongzhaigang, China
}

\author{
Wei $\mathrm{Li}^{1-3}$, Wei Guan ${ }^{4}$, Huai Chen ${ }^{2,3 *}$, Baowen Liao ${ }^{4}$, Ji Hü,3 Junpeng Rui², \\ Changhui Peng ${ }^{5,6}$, Dan $\mathrm{Zhu}^{2,3}$, Yixin $\mathrm{He}^{2,3}$, Jianqing Tian ${ }^{7 * *}$ \\ ${ }^{1}$ School of Ecology and Environmental Sciences and Yunnan Key Laboratory for Plateau Mountain Ecology \\ and Restoration of Degraded Environments, Yunnan University, Kunming, China \\ ${ }^{2}$ Key Laboratory of Mountain Ecological Restoration and Bioresource Utilization and Ecological Restoration \\ Biodiversity Conservation Key Laboratory of Sichuan Province, Chengdu Institute of Biology, \\ Chinese Academy of Sciences, Chengdu, China \\ ${ }^{3}$ Zoige Peatland and Global Change Research Station, Chinese Academy of Sciences, Hongyuan, China \\ ${ }^{4}$ Research Institute of Tropical Forestry, Chinese Academy of Forestry, Guangzhou, China \\ ${ }^{5}$ Laboratory for Ecological Forecasting and Global Change, Northwest A\&F University, Yangling, China \\ ${ }^{6}$ Institut des Sciences de l'Environnement, Université du Québec à Montréal, Montréal, Canada \\ ${ }^{7}$ State Key Laboratory of Mycology, Institute of Microbiology, Chinese Academy of Sciences, Beijing, China
}

Received: 18 January 2018

Accepted: 17 April 2018

\begin{abstract}
Archaea communities widely exist in mangrove forest sediments, but their spatial variations among different distribution areas with salinity gradient in mangrove forest sediments is not well understood. This study used 16S rRNA Miseq sequence to investigate the sediment archaeal community structure and diversity of Bruguiera gymnoihiza mangrove forest in China along three different distribution areas. The results showed rich methanogen and ammonia-oxidizing archaea resources in the study site, with Methanobacterium, Methanothrix, Methanomassiliicoccus, Nitrosopumilus and Nitrososphaera (>1\%) as the dominant genera. Mantel test and Redundancy analysis (RDA) results revealed that $\mathrm{pH}$ was the determinant for archaeal community structure in our study. The RDA result showed that the available $\mathrm{K}$ also contributed to archaeal community structure. There was a significant and positive relationship between $\mathrm{pH}$ and available $\mathrm{P}$; in addition, the two values were significantly and negatively related to the observed OTU number. These results suggested that $\mathrm{pH}$ is the main determinant of the archaeal community structure and diversity in distribution areas of Bruguiera gymnoihiza in Dongzhaigang.
\end{abstract}

Keywords: salinity, $\mathrm{pH}$, archaeal communities, mangrove sediment

\footnotetext{
*e-mail: chenhuai@cib.ac.cn,

**e-mail: Jianqingtianjq@im.ac.cn

$\$$ These authors contributed equally to the work.
} 


\section{Introduction}

Mangrove forests are widely distributed in 123 countries of the world with a total area of about $145,000 \mathrm{~km}^{2}$ under the inter-tidal region of the tropical and subtropical zones [1]. Mangrove forests as the net source of greenhouse gases (methane and nitrous oxide) with high productivity and rich carbon [2] should never be ignored in a greenhouse gas budget. Mangrove forests provide a unique ecological environment for diverse microbial communities [3], including archaea, which plays an important role in greenhouse gas production from natural wetland. A large number of studies have investigated the composition of archaea communities in different mangrove forest sediments [4-13]. Mangrove sediment archaeal community patterns were influenced by environmental conditions [5], and studies in mangrove forests also revealed that $\mathrm{pH}$ was the most influential factor in shaping the archaeal communities [14]. However, mangrove forest sediment is a high salinity environment with salt and fresh water from periodic tides and rivers, and few studies have reported the archaea communities and diversity in sediments of mangrove forest distribution areas with salinity gradients. Previous studies about the response of archaea communities to salinity gradients were mainly restricted to solar salterns [15-20], estuaries [21, 22], lakes [23] and sedimentary rocks [24]. Studies indicated that systematic changes in archaea community composition were correlated with the salinity gradient [23], and that salinity played a role in affecting archaea community structure [21, 24], diversity and distribution [22]. Archaea $16 \mathrm{~S}$ rRNA diversity was found to be higher in ponds with total salts of 370 and $380 \mathrm{~g} / \mathrm{L}$ than those of $180 \mathrm{~g} / \mathrm{L}$ [15]. The richness of archaea genera was shown to decrease apparently with the salinity gradient, with a decreasing number of different clusters until only one cluster was dominant [17]. A study incubating mangrove sediment in laboratory microcosms showed that ammonia-oxidizing archaea (AOA) might have species specificity to salinity, and that high salinity inhibited AOA between 5 and 10 days of incubation [25]. So far, no consensus has yet emerged on the responses of archaea to salinity, and it is still unclear how environmental variables affect the community structure and diversity of archaea along the salinity gradient distribution areas of mangrove forests.

The Dongzhaigang National Nature Reserve, with a total area of 4,000 ha, is the largest nature reserve of mangroves in China. Bruguiera gymnoihiza is the typical mangrove along Yanfengdong Lake, and the distribution areas of Bruguiera gymnoihiza along the upstream, midstream and downstream of Yanfengdong Lake were in salinity gradients. To date, though the archaea community in Dongzhaigang mangrove sediments has been investigated $[6,26]$, there is no research about the variation of the archaea community among sediments of Bruguiera gymnoihiza in different salinity gradient distribution areas in Dongzhaigang mangrove forest.
This study aimed to investigate the archaea community structure, abundance and diversity of Bruguiera gymnoihiza sediments in different distribution areas with Miseq platform, and then to explore the key factors affecting the archaeal community structure and diversity in distribution areas of Bruguiera gymnoihiza in Dongzhaigang.

\section{Material and Methods}

\section{Site Description}

Our sampling sites were selected along the salinity transect in the Dongzhaigang National Nature Reserve $\left(110^{\circ} 32^{\prime}-110^{\circ} 37^{\prime} \mathrm{E}\right.$ and $\left.19^{\circ} 51^{\prime}-20^{\circ} 01^{\prime} \mathrm{N}\right)$ the northeast of Donghai Port of Qiongshan City, China. The climate type, average annual rainfall and mean annual temperature in this reserve were described previously [26]. This mangrove wetland belongs to subtropical marine and coastal wetland, and mangrove communities distributed on the shore. Yanfengdong Lake is one the important lakes in the western part of Dongzhaigang National Nature Reserve, and Bruguiera gymnoihiza was the dominant community distributed along this lake. The 3 sampling plots of this research were set up in 2011 in the Bruguiera gymnoihiza (B. gymnoihiza) community based on its distribution areas along the upstream, midstream and downstream of Yanfengdong Lake. According to the salinity measured from 2012 to 2013 , the upstream plot had a low salinity (average $6.95 \%$ ), the midstream plot medium salinity (12.31\%o), and the downstream plot high salinity (15.58\%o). For each sampling plot, we set up one permanent sampling area of $20 \times 20 \mathrm{~m}$ in the bare wetland without mangrove trees.

\section{Sediment Sampling and Sediment Nutriments Analysis}

We randomly collected 6 sediment samples ( 2 from each sampling plot, 0 to $10 \mathrm{~cm}$ deep) in March 2013. All samples were then transported on ice to the Chengdu Institute of Biology, and stored at $-20^{\circ} \mathrm{C}$ until processing. Sediment $\mathrm{pH}$ and other chemical properties such as soil exchangeable calcium $\left(\mathrm{Ca}^{2+}\right)$ and magnesium $\left(\mathrm{Mg}^{2+}\right)$, total phosphorus (TP), available phosphorus (AP), total potassium (TK), available potassium (AK), total organic carbon (TOC), organic matter (OM), total nitrogen (TN), water-dissolvable nitrogen ( $\mathrm{SN})$ and salinity were measured as previously described [26].

\section{Soil DNA Extraction}

From each of the 6 sediment samples for archaea community analysis, Genomic DNA was extracted using UltraCleanTMSoil DNA Isolation Kit (MOBIO Laboratories, Carlsbad, CA, USA) according to the manufacturer's instructions. Total DNA for each 
sample was extracted three times and thoroughly mixed together. The DNA quality was checked by a NanoDrop spectrophotometer. Extracted DNA was diluted to $10 \mathrm{ng}$ $\mathrm{ul}^{-1}$ and stored at $-20^{\circ} \mathrm{C}$ until further use.

\section{Archaea 16S rRNA Amplification and Miseq Sequencing}

Archaea 16S rRNA genes were amplified in triplicate using the following universal primers 349F (5'-GYGCASCAGKCGMGAAW-3') and 806R (5'-GGACTACVSGGGTATCTAAT-3'). The PCR reaction system and detailed PCR conditions were described previously [26]. Total PCR products for each sample were amplified three times and thoroughly mixed. The methods to purify all PCR samples were the same as previously described [26]. The purified library was diluted, denatured, re-diluted, mixed with PhiX, and then sequenced using an Illumina Miseq system [27].

\section{Processing of Pyrosequencing Data}

The archaea primer $349 \mathrm{~F}$ and $806 \mathrm{R}$ revealed $13-44 \%$ archaeal sequences in this study, and the non-archaeal sequences were deleted in case of the possibility of biased sequences [28]. The QIIME Pipeline was used to process the raw sequences, and the raw archaeal sequences were classified, denoised and trimmed [29]. The aligned sequences were checked for removing chimeras by screening and filtering. Then sequences were clustered into operational taxonomic units (OTUs) based on a 97\% sequence similarity, and the representative sequence for each sample was achieved and an OTU table was built. At last, Shannon's diversity index, Simpson index and Chaol estimator at $97 \%$ sequence identity were calculated in QIIME based on the OTU table [30].The phylogenetic affiliation of each sequence was analyzed by RDP Classifier on RDPipeline (https://pyro.cme.msu.edu/classifier/form. spr) at a confidence level of $80 \%$.

\section{Statistical Analysis}

Principal coordinate analysis (PCoA) in Fast UniFrac was used to evaluate the overall structural change of archaeal communities. Reduandancy analysis (RDA) was performed to quantify the relative contributions of environmental variables to archaeal community structure variation. The Mantel test was applied to evaluate the correlations between archaeal communities with environmental variables using the Mantel procedure in the $\mathrm{R}$ package Vegan. The correlations among dominant archaea communities (order and genus levels), archaeal diversity and soil property variables were examined by Pearson's correlation analysis. All graphs were made with Origin 8.1 software, and correlation analysis were performed with SPSS 16.0. Values were considered significant when $\mathrm{P}<0.05$.

\section{Results and Discussion}

\section{Overall Archaeal Community Structure and Diversity}

The principal coordination analysis (PCoA) about the overall composition and structure of sediment archaea communities showed that samples under the same reaches were closely clustered using a weighted Unifrac distance (Fig. 1). The Mantel test further confirmed that the difference in archaeal community structure was significantly correlated with $\mathrm{pH}(\mathrm{P}<0.05)$ (Table 1). Our result showed that samples from the same reaches clustered closely (Fig. 1), which was probably because the overall archaeal community structure from sediments of three distribution areas in the Bruguiera gymnoihiza community differed from each other. Sediment salinity gradients were in our three distribution areas of Bruguiera gymnoihiza community, and even salinity was shown to be the dominating factor affecting archaeal community structure and ecological function in estuary sediments [21, 22], our Mantel test result revealed that $\mathrm{pH}$ was significantly correlated with the overall archaeal community structure $(\mathrm{P}<0.05$, Table 1).

The results of OTU number, Chaol richness and Shannon's diversity all showed the greatest archaeal diversity in the samples from upstream and the lowest diversity in those from the midstream (Table 2). Comparison of sediments of the three distribution areas showed that the midstream sediments had the maximum values of available $\mathrm{P}$ and $\mathrm{pH}$ (Table $\mathrm{S} 1$ ); and on the other hand the correlation analysis found available $\mathrm{P}$ and $\mathrm{pH}$ significantly and negatively correlated with the observed OTU number (Table S3). Since calculations of diversity were based on the OTU number, plus the significant and positive correlation between $\mathrm{pH}$ and available $\mathrm{P}$ (Table S2), we considered $\mathrm{pH} \mathrm{P}$ to be the main

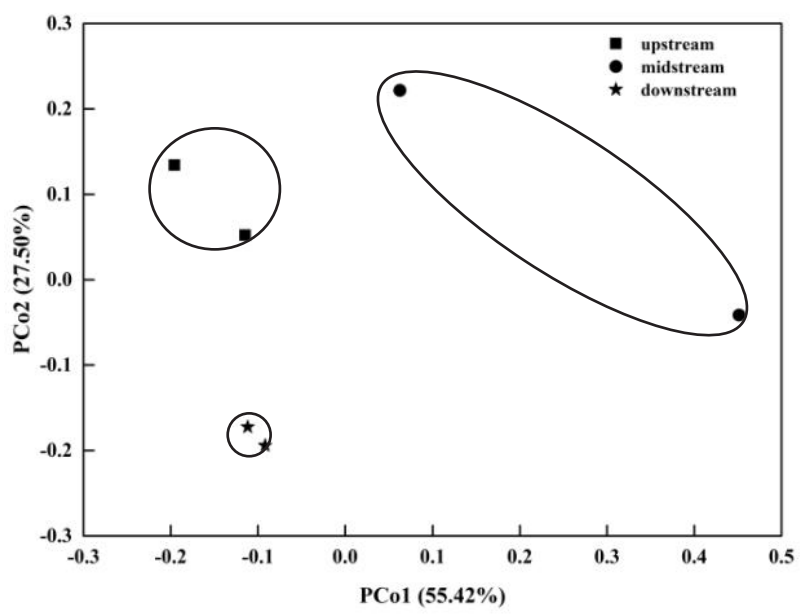

Fig. 1. Results of principal coordinate analysis (PCoA) based on the whole archaeal communities at the OTU level in Bruguiera gymnoihiza sediments of three distribution areas. 
Table 1. Pearson's correlation of environmental variables with archaeal community structure as determined by the Mantel test $\mathrm{t}^{\mathrm{a}}$.

\begin{tabular}{|c|c|c|}
\hline Variable & $\begin{array}{c}\text { Pearson correlation } \\
\text { coefficient }(r)\end{array}$ & $P$ \\
\hline Salinity & 0.182 & 0.247 \\
\hline $\mathrm{Ca}^{2+}$ content & -0.005 & 0.419 \\
\hline $\mathrm{Mg}^{2+}$ content & 0.308 & 0.129 \\
\hline Total P & -0.368 & 0.890 \\
\hline Available P & 0.184 & 0.279 \\
\hline Total K & 0.094 & 0.378 \\
\hline Available K & 0.265 & 0.200 \\
\hline pH & 0.576 & $0.035 *$ \\
\hline Organic Matter & 0.386 & 0.067 \\
\hline Total N & 0.367 & 0.065 \\
\hline Soluble N & 0.288 & 0.156 \\
\hline TOC & 0.340 & 0.119 \\
\hline
\end{tabular}

${ }^{a}$ Permutations, 9,999 (the relative abundances of OTU as input).

determinant for archaeal diversity in the Bruguiera gymnoihiza mangrove sediments of three distribution areas. This result was consistent with other studies finding that $\mathrm{pH}$ was the main factor to determine microbial diversity [31-34].

\section{Dominant Archaea Groups}

Analysis of community structure showed that the archaeal community of the sediments from the Bruguiera gymnoihiza mangrove plots of three distribution areas was constituted at the phylum level by Aenigmarchaeota, Crenarchaeota, Diapherotrites, Euryarchaeota, Pacearchaeota, Thaumarchaeota and Woesearchaeota, among them Euryarchaeota being the dominant phylum (35.55-40.94\%) (Fig. 2). All of the detected archaea at phylum level were most abundant in the downstream mangrove plot, except Pacearchaeota and Thaumarchaeota, which showed the highest abundance in midstream mangrove plot (Fig. 2). The abundant orders were methanogen and ammoniaoxidizing archaea, including Methanobacteriales,

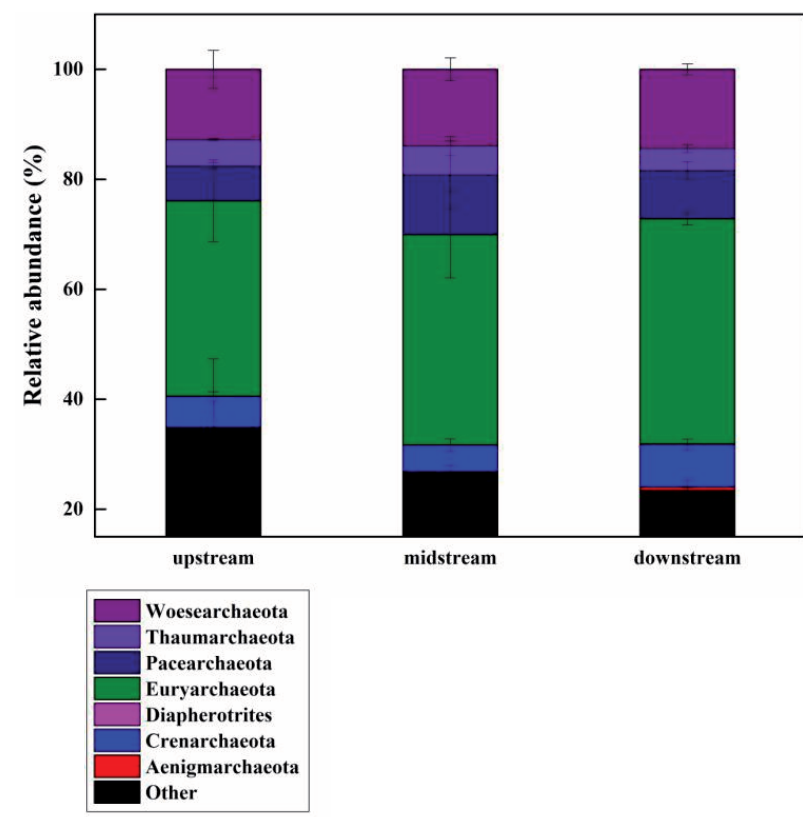

Fig. 2. Archaeal communities at the phylum level in Bruguiera gymnoihiza sediments of three distribution areas.

Methanomicrobiales, Methanosarcinales and Methanomassiliicoccales from Euryarchaeota, and Nitrososphaerales from Thaumarchaeota ( $>1 \%$, Fig. 3). The total abundance of methanogen at order level was the maximum (35.03\%) in the downstream mangrove plot and the minimum (28.88\%) in upstream plot; on the other hand, the total abundance of ammonia-oxidizing archaea at order level was the maximum (5.21\%) in the midstream mangrove plot and the minimum (3.95\%) in the downstream one (Fig. 3). Halophilic Archaea of the order Halobacteriales was also detected in our three mangrove plots with a small relative abundance $(<1 \%$, Fig. 3). In the genus level, Methanobacterium, Methanothrix and Nitrososphaera were the dominant archaea ( $>1 \%$, Fig. 3).

The present study used Miseq Illumina Sequencing Platform to evaluate the archaea community structure and diversity in the Bruguiera gymnoihiza mangrove sediments of three distribution areas in Dongzhaigang mangrove forest. Compared with the phyla Crenarchaeota and Euryarchaeota reported by the only study in this region [6], we also found Aenigmarchaeota,

Table 2. Archaeal diversity index at $97 \%$ sequence similarity at a depth of 1,360 sequences.

\begin{tabular}{|c|c|c|c|}
\hline & Upstream & Midstream & Downstream \\
\hline Chao1 estimator of richness & $555.15 \pm 37.62$ & $494.97 \pm 95.87$ & $538.11 \pm 16.13$ \\
\hline Observed OTUs number & $293.35 \pm 25.35$ & $223.45 \pm 52.45$ & $281.85 \pm 6.85$ \\
\hline Shannon's diversity index & $6.70 \pm 0.30$ & $5.94 \pm 0.76$ & $6.38 \pm 0.00$ \\
\hline Simpson's diversity index & $0.98 \pm 0.01$ & $0.96 \pm 0.02$ & $0.96 \pm 0.00$ \\
\hline
\end{tabular}

All data are mean \pm SE, $n=2$. 


\begin{tabular}{|c|c|c|c|c|c|c|c|}
\hline Order & Genus & ups & eam & mid: & ream & down & tream \\
\hline Halobacteriales & & 0.08 & 0.85 & 0.37 & 0.00 & 0.09 & 0.18 \\
\hline Methanobacteriales & & 4.31 & 2.21 & 5.69 & 24.79 & 2.65 & 1.71 \\
\hline & Methanobacterium & 3.53 & 1.68 & 5.22 & 24.62 & 1.84 & 1.40 \\
\hline & Methanobrevibacter & 0.48 & 0.13 & 0.37 & 0.03 & 0.09 & 0.02 \\
\hline Methanocellales & & 1.04 & 0.24 & 0.56 & 0.35 & 0.47 & 0.36 \\
\hline & Methanocella & 1.04 & 0.24 & 0.56 & 0.35 & 0.47 & 0.36 \\
\hline Methanomicrobiales & & 5.21 & 2.28 & 2.14 & 1.48 & 7.09 & 5.29 \\
\hline & Methanogenium & 0.09 & 0.08 & 0.19 & 0.07 & 0.51 & 0.20 \\
\hline & Methanolinea & 1.06 & 0.39 & 0.19 & 0.08 & 0.81 & 0.80 \\
\hline & Methanoregula & 0.24 & 0.36 & 0.47 & 0.16 & 0.38 & 0.47 \\
\hline & Methanospirillum & 0.08 & 0.05 & 0.09 & 0.01 & 0.09 & 0.04 \\
\hline Methanosarcinales & & 20.25 & 16.15 & 11.65 & 12.88 & 20.08 & 17.16 \\
\hline & Methanosarcina & 1.72 & 2.07 & 0.28 & 0.00 & 0.47 & 0.64 \\
\hline & Methanothrix & 6.16 & 7.11 & 6.62 & 6.97 & 10.42 & 7.22 \\
\hline Methanomassiliicocc & cales & 4.49 & 1.58 & 4.19 & 1.49 & 6.49 & 8.76 \\
\hline & Methanomassiliicocct & 4.49 & 1.58 & 4.19 & 1.49 & 6.49 & 8.76 \\
\hline Thermoplasmatales & & 3.81 & 1.52 & 1.96 & 0.54 & 0.56 & 0.82 \\
\hline Nitrosopumilales & & 1.04 & 1.88 & 1.12 & 2.80 & 0.38 & 0.69 \\
\hline & Nitrosopumilus & 1.04 & 1.88 & 1.12 & 2.80 & 0.38 & 0.69 \\
\hline Nitrososphaerales & & 3.72 & 2.67 & 5.78 & 0.72 & 4.36 & 2.47 \\
\hline & Nitrososphaera & 3.72 & 2.67 & 5.78 & 0.72 & 4.36 & 2.47 \\
\hline
\end{tabular}

Fig. 3. Abundance of dominant archaeal communities at the order and genus levels in Bruguiera gymnoihiza sediments of three distribution areas.

Diapherotrites, Pacearchaeota, Thaumarchaeota and Woesearchaeota in the Bruguiera gymnoihiza sediments (Fig. 2), suggesting that the Miseq sequencing could detect almost the full range of major archaea phyla with high coverage and depth. Mangrove forests be regarded as a source of methane and nitrous oxide [35-37], which was supported by the existence of functional archaea groups related to methane and nitrous oxide production, including methanogen and ammonia-oxidizing archaea (Fig. 3). For the 7 orders of methanogens classified by recent research [38], we found 5 of them except Methanococcales and Methanopyrales (Fig. 3). This result was consistent with one study in sediments of the northern South China Sea and MaiPo mangrove wetland, which also failed to detect Methanococcales or Methanopyrales [39]. Since Methanopyrales as represented by one species (Methanopyruskandleri) was hyperthermophilic with growing temperatures ranging from 84 to $110^{\circ} \mathrm{C}$ [40], it was natural that this order be absent in mangrove sediments with mean annual temperature less than $25^{\circ} \mathrm{C}$. The order Methanococcalesis was usually classified into two families, with the hyperthermophilic Methanocaldococcaceae and the extremely thermophilic or mesophilic Methanococcaceae [41]. Though Methanococcales are often detected from marine and salt marsh sediments [42, 43], they were not found in our study, probably due to the primer bias. The existence of the seventh order of methanogens (Methanomassiliicoccales) in our sampling plots meant that Methanomassiliicoccales were well distributed in mangrove sediments. Genera Nitrosopumilus and Nitrososphaera were found in sediments with a $\mathrm{pH}$ from 3.67 to 5.20 , which agreed with the conclusion that AOA occur widely in acidic environments [44]. Halophilicarchaea of the order Halobacteriales were also found in our salt mangrove sediments, consistent with its existence in hypersaline environments [42, 45, 46]. In summary, the Dongzhaigang mangrove forest was rich in functional archaea for carbon and nitrogen cycles.

Correlations between the Archaea Communities, Diversity and Environmental Variables

The physical-chemical characteristics of Bruguiera gymnoihiza mangrove sediments of three distribution areas are shown in Table S1. The correlation analysis showed that sediment from the upstream mangrove plot was rich in soil nutrients (Table S2). For physicalchemical characteristics, salinity was significantly and negatively correlated with $\mathrm{Ca}^{2+}(\mathrm{R}=-0.845$, $\mathrm{P}<0.05), \mathrm{Mg}^{2+}(\mathrm{R}=-0.929, \mathrm{P}<0.05)$, organic matter $(\mathrm{R}=-0.906, \mathrm{P}<0.05)$, total $\mathrm{N}(\mathrm{R}=-0.929, \mathrm{P}<0.01)$, soluble $\mathrm{N}(\mathrm{R}=-0.959, \mathrm{P}<0.01)$ and TOC $(\mathrm{R}=-0.910$, $\mathrm{P}<0.05)$, but positively correlated with total $\mathrm{K}$ $(\mathrm{R}=0.954, \mathrm{P}<0.01)$ (Table $\mathrm{S} 2)$.

For all the archaeal communities, salinity was just significantly and positively correlated with Methanothrix $(\mathrm{R}=0.830, \mathrm{P}<0.05) \quad($ Table $\mathrm{S} 3)$. Methanomicrobiales had significant and negative correlations with available $\mathrm{K}(\mathrm{R}=-1.000, \mathrm{P}<0.01)$ and $\mathrm{pH}(\mathrm{R}=-0.954, \mathrm{P}<0.01)$, while Nitrosopumilales and Nitrosopumilus were significantly and positively correlated with available $\mathrm{K}$ $(\mathrm{R}=0.954, \mathrm{P}<0.05)$ and $\mathrm{pH}(\mathrm{R}=0.907, \mathrm{P}<0.05)$ (Table $\mathrm{S} 3)$. There was significant negative correlation between Methanosarcinales and available $\mathrm{P}(\mathrm{R}=-0.903, \mathrm{P}<0.05)$, 
Table 3. R square of RDA showing the effects of sediment properties on archaeal community structure.

\begin{tabular}{|l|c|c|c|c|c|c|c|c|c|c|c|c|}
\hline & Salinity & $\begin{array}{c}\mathrm{Ca}^{2+} \\
\text { content }\end{array}$ & $\begin{array}{c}\mathrm{Mg}^{2+} \\
\text { content }\end{array}$ & $\begin{array}{c}\text { Total } \\
\mathrm{P}\end{array}$ & $\begin{array}{c}\text { Available } \\
\mathrm{P}\end{array}$ & $\begin{array}{c}\text { Total } \\
\mathrm{K}\end{array}$ & $\begin{array}{c}\text { Available } \\
\mathrm{K}\end{array}$ & $\mathrm{pH}$ & $\begin{array}{c}\text { Organic } \\
\text { Matter }\end{array}$ & $\begin{array}{c}\text { Total } \\
\mathrm{N}\end{array}$ & $\begin{array}{c}\text { Soluble } \\
\mathrm{N}\end{array}$ & $\begin{array}{c}\mathrm{TOC} \\
\mathrm{R}^{2}\end{array}$ \\
\hline & 0.2492 & 0.272 & 0.3022 & 0.1635 & 0.2476 & 0.2904 & $0.3799^{*}$ & $0.4295^{*}$ & 0.3161 & 0.3087 & 0.2608 & 0.3219 \\
\hline
\end{tabular}

$* p<0.05$

Table S1. Physical-chemical characteristics of Bruguiera gymnoihiza sediments of three distribution areas.

\begin{tabular}{|c|c|c|c|}
\hline & Upstream & Midstream & Downstream \\
\hline $\mathrm{Ca}^{2+}(\%)$ & $0.28 \pm 0.03$ & $0.19 \pm 0.01$ & $0.14 \pm 0.01$ \\
\hline $\mathrm{Mg}^{2+}(\%)$ & $0.37 \pm 0.01$ & $0.26 \pm 0.00$ & $0.20 \pm 0.00$ \\
\hline Total P (\%) & $0.15 \pm 0.03$ & $0.12 \pm 0.00$ & $0.09 \pm 0.03$ \\
\hline Available P (mgkg-1) & $31.33 \pm 4.95$ & $43.27 \pm 1.89$ & $1.03 \pm 0.06$ \\
\hline Total K (\%) & $0.47 \pm 0.03$ & $0.74 \pm 0.04$ & $181.00 \pm 67.84$ \\
\hline Available K (mg kg-1) & $628.75 \pm 23.82$ & $837.09 \pm 11.31$ & $15.58 \pm 0.60$ \\
\hline Salinity (\%) & $6.95 \pm 0.46$ & $12.31 \pm 0.80$ & $3.67 \pm 0.25$ \\
\hline $\mathrm{pH}$ & $3.94 \pm 0.10$ & $5.20 \pm 0.27$ & $6.73 \pm 0.28$ \\
\hline Organic matter $(\%)$ & $22.11 \pm 0.39$ & $12.89 \pm 1.02$ & $0.17 \pm 0.01$ \\
\hline TN (\%) & $0.67 \pm 0.00$ & $0.41 \pm 0.02$ & $128.63 \pm 2.24$ \\
\hline Soluble N (mgkg $\left.{ }^{-1}\right)$ & $522.50 \pm 31.75$ & $257.50 \pm 1.44$ & $4.41 \pm 0.45$ \\
\hline TOC (\%) & $12.83 \pm 0.22$ & $7.48 \pm 0.59$ & \\
\hline
\end{tabular}

All data are mean \pm SE, $n=2$.

and between Methanomassiliicoccales and avaiblable $\mathrm{K}(\mathrm{R}=-0.856, \mathrm{P}<0.05)$ (Table $\mathrm{S} 4)$. Methanogenium $(\mathrm{R}=-0.872, \mathrm{P}<0.05)$ and Methanomassiliicoccus $(\mathrm{R}=-0.856, \mathrm{P}<0.05)$ were significantly and negatively correlated with available K (Table S3). Methanolinea was significantly and negatively correlated with available $\mathrm{P}(\mathrm{R}=-1.000, \mathrm{P}<0.01)$ and $\mathrm{pH}(\mathrm{R}=-0.903$, $\mathrm{P}<0.05$ ) (Table $\mathrm{S} 3$ ). The relative abundance of some archaeal communities at order or genus level were significantly correlated with $\mathrm{pH}$ (Table S3). Available

Table S2. Pearson's correlation among environmental variables.

\begin{tabular}{|c|c|c|c|c|c|c|c|c|c|c|c|}
\hline & Salinity & $\mathrm{Ca}^{2+}$ & $\mathrm{Mg}^{2+}$ & $\mathrm{TP}$ & $\mathrm{AP}$ & $\mathrm{TK}$ & $\mathrm{AK}$ & $\mathrm{pH}$ & $\mathrm{SOM}$ & $\mathrm{TN}$ & $\mathrm{SN}$ \\
\hline $\mathrm{Ca}^{2+}$ & $-.845^{*}$ & & & & & & & & & & \\
\hline $\mathrm{Mg}^{2+}$ & $-.929^{* *}$ & $.933^{* *}$ & & & & & & & & & \\
\hline $\mathrm{TP}$ & -.468 & .794 & .557 & & & & & & & & \\
\hline $\mathrm{AP}$ & .148 & .175 & -.117 & .556 & & & & & & & \\
\hline $\mathrm{TK}$ & $.954^{* *}$ & $-.936^{* *}$ & $-.937^{* *}$ & -.668 & -.129 & & & & & & \\
\hline $\mathrm{AK}$ & -.552 & .554 & .529 & .481 & .558 & -.706 & & & & & \\
\hline $\mathrm{pH}$ & -.136 & .159 & .013 & .343 & $.822^{*}$ & -.318 & .810 & & & & \\
\hline $\mathrm{OM}$ & $-.906^{*}$ & $.891^{*}$ & $.990^{* *}$ & .512 & -.148 & $-.912^{*}$ & .560 & .010 & & & \\
\hline $\mathrm{TN}$ & $-.929^{* *}$ & $.882^{*}$ & $.983^{* *}$ & .497 & -.105 & $-.936^{* *}$ & .631 & .103 & $.993^{* *}$ & & \\
\hline $\mathrm{SN}$ & $-.959^{* *}$ & .789 & $.948^{* *}$ & .318 & -.335 & $-.881^{*}$ & .464 & -.051 & $.950^{* *}$ & $.957^{* *}$ & \\
\hline $\mathrm{TOC}$ & $-.910^{*}$ & $.899^{*}$ & $.986^{* *}$ & .556 & -.146 & $-.916^{*}$ & .543 & .000 & $.996^{* *}$ & $.986^{* *}$ & $.943^{* *}$ \\
\hline
\end{tabular}

$* p<0.05, * * P<0.01$. 
$\mathrm{P}$, which was significantly related to $\mathrm{pH}$, showed significant correlation with the relative abundance of Methanosarcinales and Methanolinea (Table S3). $\mathrm{R}$ square of RDA showed that $\mathrm{pH}$ and available K significantly accounted for $42.95 \%$ and $37.99 \%$ contribution to overall archaeal community structure variation $(\mathrm{P}<0.05)$ (Table 3$)$. These results indicated that $\mathrm{pH}$ was the main driving factor for overall archaeal community structure, which was consistent with the key role of soil $\mathrm{pH}$ in shaping microbial community structure in lake sediments [47], arable soils [48], continental-scale soils [31, 34], arctic soils [33], and wetland soils [32].
For archaeal diversity, only available $\mathrm{P}$ $(\mathrm{R}=-0.837, \mathrm{P}<0.05)$ and $\mathrm{pH}(\mathrm{R}=-0.858, \mathrm{P}<0.05)$ were significantly correlated with Observed OTUs number (Table S3). Though $\mathrm{pH}$ was determined as the main factor shaping microbial diversity, its effect differs for different microbial groups. It was shown to have a significant positive effect on bacterial diversity [3134], and a significantly negative one on the archaeal communities in our study. We considered the main reason being that some archaeal communities prefer acidic environments, for example, Thermoplasmatales are extremely acidophilic, growing optimally at $\mathrm{pH}$ less than 2 [49]. Other studies also reported that archaeal

Table S3. Pearson's correlation of dominant order, genera and archaeal diversity indexes with environmental variables.

\begin{tabular}{|c|c|c|c|c|c|c|c|c|c|c|c|c|}
\hline & Salinity & $\mathrm{Ca}^{2+}$ & $\mathrm{Mg}^{2+}$ & TP & AP & TK & AK & $\mathrm{pH}$ & $\mathrm{OM}$ & $\mathrm{TN}$ & SN & TOC \\
\hline \multicolumn{13}{|c|}{ (Order) } \\
\hline Halobacteriales & .062 & .231 & .416 & .490 & -.013 & -.231 & -.170 & -.081 & .416 & .416 & -.123 & .416 \\
\hline Methanobacteriales & -.252 & .123 & .062 & -.332 & .490 & -.123 & .708 & .552 & .062 & .062 & .416 & .062 \\
\hline Methanocellales & -.102 & -.288 & -.164 & -.743 & -.572 & .288 & -.252 & -.408 & -.164 & -.164 & .164 & -.164 \\
\hline Methanomicrobiales & .490 & -.552 & -.490 & -.416 & -.789 & .552 & $-1.000 * *$ & $-.954 * *$ & -.490 & -.490 & -.393 & -.490 \\
\hline Methanosarcinales & -.164 & -.062 & -.123 & -.393 & $-.903 *$ & .062 & -.692 & -.806 & -.123 & -.123 & .231 & -.123 \\
\hline Methanomassiliicoccales & .482 & -.611 & -.507 & -.280 & -.676 & .611 & $-.856^{*}$ & -.743 & -.507 & -.507 & -.579 & -.507 \\
\hline Thermoplasmatales & -.557 & .393 & .578 & -.062 & -.566 & -.393 & -.117 & -.273 & .578 & .578 & .490 & .578 \\
\hline Nitrosopumilales & -.579 & .708 & .604 & .572 & .743 & -.708 & $.954 *$ & $.907^{*}$ & .604 & .604 & .482 & .604 \\
\hline Nitrososphaerales & .191 & -.252 & -.005 & -.511 & -.334 & .252 & -.312 & -.401 & -.005 & -.005 & .005 & -.005 \\
\hline \multicolumn{13}{|c|}{ (Genus) } \\
\hline Methanobacterium & -.252 & .123 & .062 & -.332 & .490 & -.123 & .708 & .552 & .062 & .062 & .416 & .062 \\
\hline Methanobrevibacter & -.619 & .455 & .578 & -.332 & -.387 & -.455 & .108 & -.161 & .578 & .578 & .783 & .578 \\
\hline Methanocella & -.102 & -.288 & -.164 & -.743 & -.572 & .288 & -.252 & -.408 & -.164 & -.164 & .164 & -.164 \\
\hline Methanogenium & .722 & -.789 & -.646 & -.530 & -.557 & .789 & $-.872 *$ & -.783 & -.646 & -.646 & -.625 & -.646 \\
\hline Methanolinea & -.102 & -.123 & -.062 & -.455 & $-1.000 * *$ & .123 & -.789 & $-.903 *$ & -.062 & -.062 & .170 & -.062 \\
\hline Methanoregula & .578 & -.511 & -.326 & .079 & -.199 & .511 & -.530 & -.327 & -.326 & -.326 & -.743 & -.326 \\
\hline Methanospirillum & .191 & -.252 & -.005 & -.511 & -.334 & .252 & -.312 & -.401 & -.005 & -.005 & .005 & -.005 \\
\hline Methanosarcina & -.393 & .490 & .552 & .355 & -.604 & -.490 & -.429 & -.475 & .552 & .552 & .332 & .552 \\
\hline Methanothrix & $.830^{*}$ & -.604 & -.646 & -.013 & .013 & .604 & -.579 & -.377 & -.646 & -.646 & -.733 & -.646 \\
\hline Methanomassiliicoccus & .482 & -.611 & -.507 & -.280 & -.676 & .611 & $-.856^{*}$ & -.743 & -.507 & -.507 & -.579 & -.507 \\
\hline Nitrosopumilus & -.579 & .708 & .604 & .572 & .743 & -.708 & $.954 *$ & $.907^{*}$ & .604 & .604 & .482 & .604 \\
\hline Nitrososphaera & .191 & -.252 & -.005 & -.511 & -.334 & .252 & -.312 & -.401 & -.005 & -.005 & .005 & -.005 \\
\hline \multicolumn{13}{|c|}{ (Diversity and richness) } \\
\hline $\begin{array}{c}\text { Chaol estimator of rich- } \\
\text { ness }\end{array}$ & -.033 & -.047 & .166 & -.125 & -.624 & .068 & -.227 & -.603 & .267 & .204 & .228 & .297 \\
\hline Observed OTUs number & -.068 & -.032 & .195 & -.237 & $-.837 *$ & .100 & -.484 & $-.858^{*}$ & .257 & .178 & .283 & .278 \\
\hline Shannon's diversity index & -.159 & .070 & .304 & -.129 & -.733 & -.030 & -.266 & -.710 & .388 & .318 & .373 & .409 \\
\hline Simpson's diversity index & -.279 & .220 & .425 & .072 & -.523 & -.214 & .029 & -.456 & .524 & .471 & .457 & .550 \\
\hline
\end{tabular}

$* p<0.05, * * P<0.01$. 
amoA gene and transcript abundance decreased with soil $\mathrm{pH}[44,50]$. The only archaeal group that positively and significantly correlated with salinity in our study was Methanothrix, also named as Methanosaeta (Table S3). The genus Methanothrix (Methanosaeta) utilizes acetate as the sole energy source [51]; a study reported the species Methanosaetapelagica as an aceticlastic and NaCl-requiring methanogen with $\mathrm{Na}^{+}$ concentrations of 0.20 to $0.80 \mathrm{M}$ [52]. This suggested that at least part of Methanosaeta are moderately halophilic, especially those in marine sediments, which might account for the increase of Methanothrix (Methanosaeta) abundance with the salinity in our study.

Salinity displayed a gradient of $6.95-15.58 \%$ along our mangrove sediments. Previous studies showed salinity as the key determinant of archaeal community structure in estuarine sediments [21, 22], but our Mantel test and RDA results revealed that salinity was not the main factor influencing archaeal communities (Tables 1, 3). A study from hypersaline sediments showed that soil properties $(\mathrm{pH}$, site water content, phosphorus and organic carbon) rather than salinity were the main factors for microbial community structure [53]. The diversified effect of salinity on microbial community structure probably depended on the details of sediment conditions. In this study, salinity significantly decreased the sediment carbon and nitrogen contents (Table S2), with their variation having no significant influence on archaeal community structure and diversity.

\section{Conclusions}

In conclusion, methanogen and ammoniaoxidizing archaea were the rich archaeal communities in Bruguiera gymnoihiza sedimemts. Even with a narrow range, $\mathrm{pH}$ value was the main determinant of the archaeal community structure and diversity in the Bruguiera gymnoihiza sedimemts of three distribution areas in Dongzhaigang.

\section{Acknowledgements}

This study was supported by the Fundamental Research Funds in Central Public Welfare Research Institutes - Chinese Academy of Forestry (CAFYBB2017MA005), the 100 Talents Program of the Chinese Academy of Sciences, the External Cooperation Program of BIC, the Chinese Academy of Sciences (No. 151751KYSB20130027), the 1000 Talents Program of Sichuan Province of China, and the National Natural Science Foundation (31570480). The authors give special thanks to Ms. Wan Xiong for her editing and valuable comments on the manuscript.

\section{Conflict of Interest}

The authors declare no conflict of interest.

\section{References}

1. SPALDING M., BLASCO F., FIELD C. World mangrove atlas. 1997.

2. DONATO D.C., KAUFFMAN J.B., MURDIYARSO D., KURNIANTO S., STIDHAM M., KANNINEN M. Mangroves among the most carbon-rich forests in the tropics. Nature Geoscience, 4 (5), 293, 2011.

3. KATHIRESAN K., BINGHAM B.L. Biology of mangroves and mangrove ecosystems. Advances in marine biology, 40 (81), 2001.

4. PIRES A.C., CLEARY D.F., ALMEIDA A., CUNHA Â., DEALTRY S., MENDON A-HAGLER L.C., SMALLA K., GOMES N C.Denaturing gradient gel electrophoresis and barcoded pyrosequencing reveal unprecedented archaeal diversity in mangrove sediment and rhizosphere samples. Applied and environmental microbiology, 78 (16), 5520, 2012.

5. BHATTACHARYYA A., MAJUMDER N.S., BASAK P., MUKHERJI S., ROY D., NAG S., HALDAR A., CHATTOPADHYAY D., MITRA S., BHATTACHARYYA M. Diversity and Distribution of Archaea in the Mangrove Sediment of Sundarbans. Archaea, 2015.

6. YAN B., HONG K., YU Z.-N. Archaeal communities in mangrove soil characterized by $16 \mathrm{~S}$ rRNA gene clones. Journal of microbiology, 44 (5), 566, 2006.

7. MENDES L.W., TAKETANI R.G., NAVARRETE A.A., TSAI S M.Shifts in phylogenetic diversity of archaeal communities in mangrove sediments at different sites and depths in southeastern Brazil. Research in microbiology, 163 (5), 366, 2012.

8. PIRES A.C.D.C. Mangrove rhizosphere effect on sediment Archael communities. 2010.

9. LYIMO T.J., POL A., JETTEN M.S., DEN CAMP H. J.O. Diversity of methanogenic archaea in a mangrove sediment and isolation of a new Methanococcoides strain. FEMS Microbiology Letters, 291 (2), 247, 2009.

10. LYIMO T.J., POL A., DEN CAMP H.O., HARHANGI H.R., VOGELS G.D. Methanosarcina semesiae sp. nov., a dimethylsulfide-utilizing methanogen from mangrove sediment. International journal of systematic and evolutionary microbiology, 50 (1), 171, 2000.

11. TAKETANI R.G., FRANCO N.O., ROSADO A.S., VAN ELSAS J.D. Microbial community response to a simulated hydrocarbon spill in mangrove sediments. The Journal of Microbiology, 48 (1), 7, 2010.

12. LI M., HONG Y.-G., CAO H.-L., GU J.-D. Mangrove trees affect the community structure and distribution of anammox bacteria at an anthropogenic-polluted mangrove in the Pearl River Delta reflected by $16 \mathrm{~S}$ rRNA and hydrazine oxidoreductase (HZO) encoding gene analyses. Ecotoxicology, 20 (8), 1780, 2011.

13. WANG Y.-F., FENG Y.-Y., MA X., GU J.-D. Seasonal dynamics of ammonia/ammonium-oxidizing prokaryotes in oxic and anoxic wetland sediments of subtropical coastal mangrove. Applied microbiology and biotechnology, 97 (17), 7919, 2013.

14. ZHOU Z., MENG H., LIU Y., GU J.D., LI M. Stratified bacterial and archaeal community in mangrove and intertidal wetland mudflats revealed by high throughput 
16S rRNA gene sequencing. Frontiers in Microbiology, 8 , 2148, 2017.

15. DILLON J.G., CARLIN M., GUTIERREZ A., NGUYEN V., MCLAIN N. Patterns of microbial diversity along a salinity gradient in the Guerrero Negro solar saltern, Baja CA Sur, Mexico. Frontiers in Microbiology, 4, 2013.

16. BOUJELBEN I., GOMARIZ M., MART NEZ-GARC A.M., SANTOS F., PE A.A., L PEZ C., ANT N.J., MAALEJ S. Spatial and seasonal prokaryotic community dynamics in ponds of increasing salinity of Sfax solar saltern in Tunisia. Antonie van Leeuwenhoek, 101 (4), 845, 2012.

17. BENLLOCH S., L PEZ-L PEZ A., CASAMAYOR E.O., ØVRE S.L., GODDARD V., DAAE F.L., SMERDON G., MASSANA R., JOINT I., THINGSTAD F. Prokaryotic genetic diversity throughout the salinity gradient of a coastal solar saltern. Environmental Microbiology, 4 (6), 349, 2002.

18. CASAMAYOR E.O., MASSANA R., BENLLOCH S., VRE S.L., D EZ B., GODDARD V.J., GASOL J.M., JOINT I., RODR GUEZ?VALERA F., PEDR S?ALI C. Changes in archaeal, bacterial and eukaryal assemblages along a salinity gradient by comparison of genetic fingerprinting methods in a multipond solar saltern. Environmental Microbiology, 4 (6), 338, 2002.

19. S RENSEN K.B., CANFIELD D.E., OREN A. Salinity responses of benthic microbial communities in a solar saltern (Eilat, Israel). Applied and environmental microbiology, 70 (3), 1608, 2004.

20. BENLLOCH S., ACINAS S.G., MART NEZ-MURCIA A., RODR GUEZ-VALERA F. Description of prokaryotic biodiversity along the salinity gradient of a multipond solar saltern by direct PCR amplification of $16 \mathrm{~S}$ rDNA [M]. Coastal Lagoon Eutrophication and ANaerobic Processes (CLE AN). Springer. 19, 1996.

21. XIE W., ZHANG C., ZHOU X., WANG P. Salinitydominated change in community structure and ecological function of Archaea from the lower Pearl River to coastal South China Sea. Applied microbiology and biotechnology, 98 (18), 7971, 2014.

22. WEBSTER G., O'SULLIVAN L.A., MENG Y., WILLIAMS A.S., SASS A.M., WATKINS A.J., PARKES R.J., WEIGHTMAN A.J. Archaeal community diversity and abundance changes along a natural salinity gradient in estuarine sediments. Fems Microbiology Ecology, 91 (2), $1,2015$.

23. JIANG H., DONG H., YU B., LIU X., LI Y., JI S., ZHANG C.L. Microbial response to salinity change in Lake Chaka, a hypersaline lake on Tibetan plateau. Environmental Microbiology, 9 (10), 2603, 2007.

24. WALDRON P.J., PETSCH S.T., MARTINI A.M., N SSLEIN K. Salinity constraints on subsurface archaeal diversity and methanogenesis in sedimentary rock rich in organic matter. Applied and environmental microbiology, 73 (13), 4171, 2007.

25. WANG Y.-F., GU J.-D. Effects of allylthiourea, salinity, and $\mathrm{pH}$ on ammonia/ammonium-oxidizing prokaryotes in mangrove sediment incubated in laboratory microcosms. Applied microbiology and biotechnology, 98 (7), 3257, 2014.

26. LI W., GUAN W., CHEN H., LIAO B., HU J., PENG C., RUI J., TIAN J., ZHU D., HE Y. Archaeal communities in the sediments of different mangrove stands at Dongzhaigang, China. Journal of Soils and Sediments, 16 (7), 1995, 2016.
27. YAO M., RUI J., LI J., DAI Y., BAI Y., HEDĚNEC P., WANG J., ZHANG S., PEI K., LIU C. Rate-specific responses of prokaryotic diversity and structure to nitrogen deposition in the Leymus chinensis steppe. Soil Biology and Biochemistry, 79 (81), 2014.

28. SATO Y., WILLIS B L., BOURNE D G. Pyrosequencingbased profiling of archaeal and bacterial 16S rRNA genes identifies a novel archaeon associated with black band disease in corals. Environmental Microbiology, 15 (11), 2994, 2013

29. CAPORASO J.G., KUCZYNSKI J., STOMBAUGH J., BITTINGER K., BUSHMAN F.D., COSTELLO E.K., FIERER N., PENA A.G., GOODRICH J.K., GORDON J.I. QIIME allows analysis of high-throughput community sequencing data. Nature methods, 7 (5), 335, 2010.

30. KUCZYNSKI J., LAUBER C.L., WALTERS W.A., PARFREY L.W., CLEMENTE J.C., GEVERS D., KNIGHT R. Experimental and analytical tools for studying the human microbiome. Nature Reviews Genetics, 13 (1), 47, 2012.

31. FIERER N., JACKSON R.B. The diversity and biogeography of soil bacterial communities. Proceedings of the National Academy of Sciences of the United States of America, 103 (3), 626, 2006.

32. HARTMAN W.H., RICHARDSON C.J., VILGALYS R., BRULAND G.L. Environmental and anthropogenic controls over bacterial communities in wetland soils. Proceedings of the National Academy of Sciences, 105 (46), 17842, 2008.

33. CHU H., FIERER N., LAUBER C.L., CAPORASO J.G., KNIGHT R., GROGAN P. Soil bacterial diversity in the Arctic is not fundamentally different from that found in other biomes. Environmental Microbiology, 12 (11), 2998, 2010.

34. LAUBER C.L., HAMADY M., KNIGHT R., FIERER N. Pyrosequencing-based assessment of soil $\mathrm{pH}$ as a predictor of soil bacterial community structure at the continental scale. Applied and environmental microbiology, 75 (15), 5111, 2009.

35. ALLEN D.E., DALAL R.C., RENNENBERG H., MEYER R.L., REEVES S., SCHMIDT S. Spatial and temporal variation of nitrous oxide and methane flux between subtropical mangrove sediments and the atmosphere. Soil Biology \& Biochemistry, 39 (2), 622, 2007.

36. LU C.Y., WONG Y.S., TAM N F., YE Y., LIN P. Methane flux and production from sediments of a mangrove wetland on Hainan Island, China. Mangroves and Salt Marshes, 3 (1), 41, 1999.

37. CHAUHAN R., DATTA A., RAMANATHAN A., ADHYA T. Factors influencing spatio-temporal variation of methane and nitrous oxide emission from a tropical mangrove of eastern coast of India. Atmospheric Environment, 107 (95), 2015.

38. BORREL G., O'TOOLE P.W., HARRIS H.M., PEYRET P., BRUG RE J.-F., GRIBALDO S. Phylogenomic data support a seventh order of methylotrophic methanogens and provide insights into the evolution of methanogenesis. Genome biology and evolution, 5 (10), 1769, 2013.

39. ZHOU Z., CHEN J., CAO H., HAN P., GU J.-D. Analysis of methane-producing and metabolizing archaeal and bacterial communities in sediments of the northern South China Sea and coastal Mai Po Nature Reserve revealed by PCR amplification of mcrA and pmoA genes. Frontiers in Microbiology, 5, 2014. 
40. LIU Y. Methanopyrales [M]//TIMMIS K N. Handbook of Hydrocarbon and Lipid Microbiology. Berlin, Heidelberg; Springer Berlin Heidelberg. 605, 2010.

41. LIU Y. Methanococcales [M]. Handbook of Hydrocarbon and Lipid Microbiology. Springer. 573, 2010.

42. ALAM I., BOUGOUFFA S., LAFI F.F., BAJIC V.B., ARCHER J.A. Rhizosphere microbiome metagenomics of gray mangroves (Avicennia marina) in the Red Sea. 2015.

43. JEMANEH ZELEKE Q.S., WANG J.-G., HUANG M.-Y., XIA F., WU J.-H., QUAN Z.-X. Effects of Spartina alterniflora invasion on the communities of methanogens and sulfate-reducing bacteria in estuarine marsh sediments. Frontiers in Microbiology, 4, 2013.

44. NICOL G.W., LEININGER S., SCHLEPER C., PROSSER J.I. The influence of soil $\mathrm{pH}$ on the diversity, abundance and transcriptional activity of ammonia oxidizing archaea and bacteria. Environmental Microbiology, 10 (11), 2966, 2008.

45. YOUSSEF N.H., ASHLOCK-SAVAGE K.N., ELSHAHED M.S. Phylogenetic diversities and community structure of members of the extremely halophilic Archaea (order Halobacteriales) in multiple saline sediment habitats. Applied and environmental microbiology, 78 (5), 1332, 2012.

46. GARCIA J.-L., OLLIVIER B., WHITMAN W.B. The order Methanomicrobiales [M]. The prokaryotes. Springer. 208, 2006.

47. XIONG J., LIU Y., LIN X., ZHANG H., ZENG J., HOU J., YANG Y., YAO T., KNIGHT R., CHU H. Geographic distance and $\mathrm{pH}$ drive bacterial distribution in alkaline lake sediments across Tibetan Plateau. Environmental Microbiology, 14 (9), 2457, 2012.

48. ROUSK J., B TH E., BROOKES P.C., LAUBER C.L., LOZUPONE C., CAPORASO J.G., KNIGHT R., FIERER N. Soil bacterial and fungal communities across a $\mathrm{pH}$ gradient in an arable soil. The ISME journal, 4 (10), 1340, 2010.

49. HUBER H., STETTER K.O. Thermoplasmatales. The Prokaryotes: Volume 3: Archaea Bacteria: Firmicutes, Actinomycetes, 101, 2006.

50. YAO H., GAO Y., NICOL G.W., CAMPBELL C.D., PROSSER J.I., ZHANG L., HAN W., SINGH B.K. Links between ammonia oxidizer community structure, abundance, and nitrification potential in acidic soils. Applied and environmental microbiology, 77 (13), 4618, 2011.

51. KENDALL M.M., BOONE D.R. The order methanosarcinales [M]. The prokaryotes. Springer. 244, 2006.

52. MORI K., IINO T., SUZUKI K.-I., YAMAGUCHI K., KAMAGATA Y. Aceticlastic and NaCl-requiring methanogen "Methanosaeta pelagica" sp. nov., isolated from marine tidal flat sediment. Applied and environmental microbiology, 78 (9), 3416, 2012.

53. HOLLISTER E.-B., ENGLEDOW A.-S., HAMMETT A.J.M., PROVIN T.L., WILKINSON H.H., GENTR T.J. Shifts in microbial community structure along an ecological gradient of hypersaline soils and sediments. The ISME journal, 4 (6), 829, 2010. 